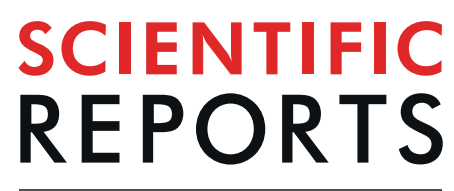

natureresearch

\title{
OPEN
}

Published online: 07 November 2019

\section{Author Correction: Phosphopantetheinyl transferase (Ppt)-mediated biosynthesis of lysine, but not siderophores or DHN melanin, is required for virulence of Zymoseptoria tritici on wheat}

Mark C. Derbyshire (D), Amir Mirzadi Gohari, Rahim Mehrabi, Sreedhar Kilaru, Gero Steinberg, Solaf Ali, Andy Bailey, Kim Hammond-Kosack, Gert H. J. Kema (iD \& Jason J. Rudd

Correction to: Scientific Reports https://doi.org/10.1038/s41598-018-35223-8, published online 20 November 2018

In the original version of this Article, Solaf Ali was incorrectly affiliated with 'School of Biological Sciences, Bristol University, 24 Tyndall Avenue, Bristol, UK'. The correct affiliation is listed below.

Technical College of Health, Sulaimani Polytechnic University, Qrga, Wrme Street, Mardin 327, Alley 76, Sulaimaniyah, Kurdistan Region of Iraq, Sulaimani Governorate, Iraq.

This error has now been corrected in the PDF and HTML versions of the Article.

\begin{abstract}
(c) (i) Open Access This article is licensed under a Creative Commons Attribution 4.0 International License, which permits use, sharing, adaptation, distribution and reproduction in any medium or format, as long as you give appropriate credit to the original author(s) and the source, provide a link to the Creative Commons license, and indicate if changes were made. The images or other third party material in this article are included in the article's Creative Commons license, unless indicated otherwise in a credit line to the material. If material is not included in the article's Creative Commons license and your intended use is not permitted by statutory regulation or exceeds the permitted use, you will need to obtain permission directly from the copyright holder. To view a copy of this license, visit http://creativecommons.org/licenses/by/4.0/.
\end{abstract}

(C) The Author(s) 2019 